\title{
Fear the Corona Pandemic? Avoid with Social Distance Using Online Art Learning Development
}

\author{
Faisal \\ Program Studi Sistem Informasi Universitas Trilogi, Jl. TMP Kalibata No. 1 Jakarta 12760 \\ \{faisalpiliang@trilogi.ac.id\}
}

\begin{abstract}
The Indonesian government announced the danger of the corona virus pandemic as a national disaster. Local governments adopted a policy to stop school activities. However, learning management strategies are needed in the process of building, refining student answers and evaluating answers using online-based services to avoid the corona virus pandemic. This research is a qualitative research with ethnographic design, using interview, observation and documentation approach. Utilizing the development model of online art learning models can avoid corona pandemics and maintain the quality of education can be applied. The development of online art learning is able to provide the desired report data online. The suggestion is online learning can be applied to other school units so that it is expected to avoid the corona pandemic and maintain the quality of education. For development, it can be implemented using a mobilebased application.
\end{abstract}

Keywords: Black box; Corona Virus Pandemic; Development of Online Art Learning; Ethnographic design qualitative research; Social Distance

\section{Introduction}

The Indonesian government has announced the danger of a corona virus pandemic as a national disaster. A number of areas have established the status of extraordinary events for the treatment of the corona virus. With the development of the spread of the corona virus, a number of local governments in Indonesia adopted a policy to stop school activities [9]. The Indonesian government also urges all companies to ask their employees to do work from home. The aim is to reduce the level of corona virus transmission by reducing contact in a larger crowd or community, also known as social distance. Social distance is a step that must be done in the middle of a corona virus that has been detected in several cities in Indonesia.

Social Keeping a distance while socializing is considered an important way to prevent the corona virus. Social distance is a method used to reduce the likelihood of disease transmission due to the corona virus. Social distance is difficult to apply, because humans are basically social creatures, which requires them to interact with each other. Social distance aims to prevent outbreaks to reduce the chance of infection among high-risk populations [3]. In addition, social distance is expected to reduce the level and extent of the spread of the corona virus in each city or community. Social distance can be done by reducing mass gatherings, not 
being in a crowded area, and keeping a distance of about two meters from the others, especially from those who show signs of disease.

President Joko Widodo (Jokowi) asks that people do social distance to prevent transmission of the corona virus. Activities that are usually carried out outside, such as work, study and worship can be done at home. At present what matters is social distance, maintaining distance [4]. In this condition, we work from home, study and worship at home. Social distance is someone who maintains physical closeness with someone to reduce the transfer of the virus from one body to another. Social distance activities are carried out as a health strategy to prevent or slow the spread of the virus. Social distance is also done by isolating themselves to infected people, quarantining themselves, so people can be separated from each other.

Minister of Education and Culture of the Republic of Indonesia Nadiem Makarim explained that a number of areas closed schools for fear of spreading the corona virus [12]. In connection with situations where school holidays take place, we need learning tools for teachers and students. Temporary delays in teaching and learning activities in schools, do not necessarily make the student learning process stop. Students can continue to learn online, teachers can continue to provide assistance in the learning process of students, and parents can monitor the progress of their children's learning. All that can be done with online based education solutions. Teachers can send text, sound and video-based teaching material through online-based education to their students. Likewise students can discuss with teachers and other students in online-based education.

However, learning management strategies are needed in the process of building, correcting student answers and assessing answers using online information and communication technology services to avoid corona pandemics. Assistance with online-based information and communication technology services is expected to accelerate the process of learning management in the process of assigning tasks, correcting answers to providing answers. The use of online-based information and communication technology services also aims to improve the quality of the learning process in schools and learning outcomes. The problem of the learning management process in the process of assigning tasks, correcting answers to give correct answers and free from mistakes is an important factor in avoiding corona ponaemics and maintaining the quality of education. The formulation of the problem in this research is how to develop a process of online learning management that is correct and error free. The aim of this research is the process of managing online art learning, error free, faster, more efficient, by utilizing information and communication technology services, so that it is expected to avoid the corona pandemic and maintain the quality of education.

\section{Literature Review}

\subsection{Social Distance}

Social distance is avoiding attendance at large gatherings or avoiding crowds of people. If you have to be around people, keep a distance from others about 6 feet ( 2 meters). Also by canceling events that tend to attract the attention of many people. Social distance deliberately increases physical space between people to avoid spreading disease. An example of social distance that allows you to avoid larger crowds or crowded spaces is recommended by Johns Hopkins Medicine [13].

a. Work from home and not in the office 
b. Close school or switch to online classes

c. Meet other people by phone or video call instead of in person

d. Cancel or postpone conferences and large meetings.

Social networking greatly influences students' daily lives, this reveals the need for measurement tools to determine social media addiction. This study aims to develop a Social Media Addiction Scale for Student Forms (SMAS-SF) and to conduct validity and reliability of scale calculations. As a result of a literature survey in Turkey, it has been observed that social media is widely used among children aged 12-22 years [15].

Social networks are examples of complex systems consisting of nodes that can interact with each other and based on this activity social relationships are defined. Online social networks are becoming popular among many people, as a source of formation of online virtual communities. This community was developed by creating a profile and maintaining each user's personal contact through social interactions. In terms of quality indicators, Iran's scientific production in the field of social networking is in a relatively favorable situation. So that a total of 880 Iranian articles in this field received 3046 citations. The citation index for each article was 3.46, which was obtained 3.64 over a five-year period [10].

The choice of distance metrics is the key to success in many machine learning and data processing tasks. The distance between two data samples traditionally depends on the value of their attributes (coordinates) in the data space. Some metrics also take into account the distribution of samples in space (eg local density) which aims to improve the classification of potential performance or grouping [21].

Al-Naibi, I., Al-Jabri, M., dan Al-Kalbani, I., 2018 measure the effectiveness of integrating Edmodo social networking site in student writing performance in EFL classrooms at the Arab Open University (Oman Branch). Participants are 25 students studying English in the Foundation Program. Along with three lesson plans that are used to teach students the writing process, students do several quizzes, discussions and activities at Edmodo [1]. Analysis of the writing of both students showed a statistically significant improvement in student writing. The post treatment questionnaire results showed that students had positive perceptions using Edmodo in language learning.

\subsection{Study Art}

Learning is the learning process provided by the teacher so that students gain knowledge and knowledge, mastery of skills, and the formation of attitudes and beliefs. Learning is the process of teaching and learning interactions between teachers and students [23]. The concept of art in education was originally put forward by the essentialist group who assumed that essential art material was given to children. So according to this concept, artistic skills such as painting, singing, dancing and so on need to be taught to children in the context of their development and preservation. This means that educational institutions and educators have a role to pass down, develop, and preserve various types of art to their students.

Law Number 19 Year 2005 explains that the subject of Art and Culture is one of the compulsory subjects for elementary and secondary level education units [22]. Cultural Arts and Skills Education is given in schools because of the uniqueness, meaningfulness, and usefulness of students' development needs, which are located in providing aesthetic experiences in the form of creative expressions or activities and appreciation through learning approaches with art, learning through art and learning about art [6].

Basically, the concept of art education consists of two types, the first is the concept of art education which is related to aspects of artistic expression and the second is the concept of art 
education which is related to educational goals [18]. Studying art at the level of basic education aims to develop awareness of art and beauty in a general sense, both in the fields of conception, appreciation, creation, presentation, and psychology education goals for the positive development of students' personalities, so that individuals better understand culture as one of the educational goals [11].

Music art learning planning using information and communication technology is carried out by compiling a complete learning tool that includes the preparation of curriculum, syllabus and learning implementation plans. The implementation of music art learning by using information and communication technology tools applies learning strategies, methods, techniques, and tactics in three parts, namely introduction, core activities, and closing [2]. Art and culture results can be used as learning material to be lived, analyzed and subsequently as a foothold in creating new arts and culture by not leaving the characteristics and culture that already exists [14].

Teachers of SMAN 1 Pulokulon have a very important role in preparing teaching materials and materials that are in accordance with the needs and characteristics of the teaching materials to be presented. Sources of materials and teaching materials used in art and culture learning at SMAN 1 Pulokulon Grobogan come from textbooks, Student Worksheets, the internet and other references relevant to learning materials to be taught such as examples of artwork. In the study of art and culture at SMAN 1, Pulokulon interactions occur in two patterns, namely teacher-centered interactions and centralized content [19].

Studying Art and Culture using an integrative thematic approach with the theme of caring for animals and plants in MIN 2 Bandar Lampung is done in two ways, namely by integrating concepts on the theme into subject matter, as well as integrating concepts from various subjects. [23] space for the optimal development of multi-intelligence students. In the pedagogical dimension, arts and culture education has a multilingual, multi-professional and multicultural nature, which can build one's character to be able to communicate in tolerance, wisdom, understanding, and togetherness [20].

Studying cultural arts and crafts for children with special needs must be able to utilize the environment as an activity of appreciation and artistic creation. Cultural arts education not only functions as the development of knowledge and skills, but becomes a means in the development of personal character based on socio-culture [7]. The orientation of arts and culture subjects is facilitating emotional, intellectual, physical, conception, social, aesthetic, artistic and creativity experiences to students by carrying out creative and creative activities on various product objects around students that are beneficial to human life, including; types, forms, functions, benefits, themes, structures, properties, compositions, raw materials, additives, equipment, strengths, and technical restrictions [16].

The distance learning model used at Trilogy University is considered sufficient, in terms of learning objectives, learning materials, interactivity, and rules. The results also show that both lecturers and students think that learning with a distance education system can simplify work, accelerate work, work accurately, and be more efficient because it is interactive and user friendly [5].

\subsection{Corona pandemic}

World health researchers warn the situation of the transmission of the corona virus (COVID-19) in Indonesia could overwhelm the government. Based on data on Wednesday, March 25, 2020, there were 58 deaths from 790 positive COVID-19 case findings in Indonesia. The percentage of corona virus patient deaths in Indonesia reached 7.34 percent, 
surpassing Malaysia with a mortality rate of 1.05 percent, the Philippines (5.05 percent), and Thailand (0.42 percent). A recent report from the Central Institute for the Model of Infectious Mathematical Diseases, says that official data currently only represent two percent of the conditions of transmission of the Corona virus in Indonesia. This London-based institution estimates that the actual number of corona virus infections in Indonesia reaches 34,300 cases $[8]$.

The number of confirmed positive cases of the COVID-19 corona virus in Indonesia continues to grow. On 3/29/2020 at 12.00 WIB the number of positive cases of COVID-19 increased by 130 . The number of deaths also increased every day, bringing the total number of deaths to 114 . While the number of patients recovering also increased, there are now a total of 64. The government officially began giving positive cases on March 2, 2020. At that time there were two positive cases, then increasing every day to this day [17].

\section{Research Methods}

The location of the study was conducted in the Madrasah Tsanawiyah Negeri 35 Jakarta area which addressed at Jl. Melati Putih RT.13 RW.6, Indonesia. This type of research is a qualitative research with ethnographic design. Data collection techniques are done using interviews, observation and documentation. Data analysis techniques using an interactive analysis model. Expert respondents and data sources in this study were obtained by distributing questionnaires to the academic community of Madrasah Tsanawiyah Negeri 35 Jakarta involved in the development of art learning, namely one school principal, one deputy headmaster, twenty teachers, one hundred students and five student administration staff. person. This research was conducted in December 2019 to April 2020. Testing of the model in this study used black box testing. Description of the interactions that occur in the study of the development of online art learning can be seen in figure 1. below.

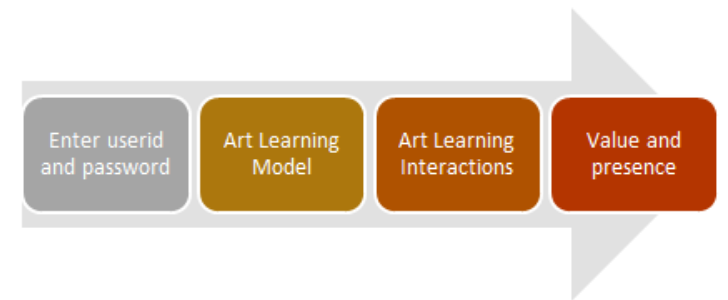

Fig. 1. Art Learning Interactions

The depiction of interactions that occur in the study of the development of online art learning in figure 1 above starts from all members of the academic community who enter the appropriate username and password to interact in the development model of online art learning. After they can enter and be on the online learning model development page, all new academic communities can interact with each other. The teacher can provide material and assignments to be learned and answered by all students. From the answers to these assignments, the teacher will be given an assessment. The process of completing the making of materials, assignments, and assignments of grades will be the presence of the teachers. Students can study the material and answer assignments given by all their teachers. From the answers to these assignments, the teacher will be given an assessment. The process of completing the assignment answers will be present for students. Administrative staff will 
recapitulate the grades given by the teacher, recapitulate the presence of teachers and students. The following is a conceptual framework in this study.

Table 1. Research Conceptual Framework

\begin{tabular}{|c|c|}
\hline Phase & Description \\
\hline $\begin{array}{l}\text { Field } \\
\text { observation }\end{array}$ & $\begin{array}{l}\text { Masukan: Input: Conduct surveys, interviews, and discussions with } \\
\text { expert respondents regarding art learning } \\
\text { Objective: To get thoughts about learning art } \\
\text { Method: Focus group discussions with expert respondents } \\
\text { Output: Analysis of art learning. }\end{array}$ \\
\hline $\begin{array}{l}\text { The depiction } \\
\text { of art learning }\end{array}$ & $\begin{array}{l}\text { Input: Conduct surveys, interviews, and discussions with expert } \\
\text { respondents to find pictures of art learning } \\
\text { Objective: To determine the features that will be used in the art } \\
\text { learning process } \\
\text { Method: Focus group discussions with expert respondents } \\
\text { Output: Description of the development of art learning. }\end{array}$ \\
\hline $\begin{array}{l}\text { Supports data } \\
\text { search }\end{array}$ & $\begin{array}{l}\text { Input: Secondary data through various media such as: internet, } \\
\text { literature books and scientific journals and supporting articles } \\
\text { Objective: To produce quality research } \\
\text { Method: Read literature books and scientific journals and supporting } \\
\text { articles } \\
\text { Outputs: Literature books and scientific journals and supporting } \\
\text { articles, as a reference list. }\end{array}$ \\
\hline $\begin{array}{l}\text { Development } \\
\text { of art learning } \\
\text { models }\end{array}$ & $\begin{array}{l}\text { Input: Theories that support the analysis of models and the } \\
\text { development of artistic learning } \\
\text { Objective: To get the expected model development } \\
\text { Method: Focus group discussions with expert respondents } \\
\text { Output: Art learning model. }\end{array}$ \\
\hline $\begin{array}{l}\text { Test the art } \\
\text { learning } \\
\text { model }\end{array}$ & $\begin{array}{l}\text { Input: Analysis of the art learning model testing. } \\
\text { Objective: Get the model tested. } \\
\text { Method: Focus group discussions with expert respondents. } \\
\text { Output: A proven art learning model. }\end{array}$ \\
\hline
\end{tabular}

\section{Results and Discussion}

\subsection{Data Analysis and Interpretation}

Description of the results of the analysis and interpretation of data from interviews with expert respondents. The expert respondents in this study were the academic community involved in the development of online art learning, namely one school principal, one deputy headmaster, twenty teachers, one hundred students and five administrative staff at the Tsanawiyah State Madrasah 35 Jakarta, located on Jl. Melati Putih RT.13 RW.6, Indonesia. The study of the development of online art learning was conducted in December 2019 to April 2020 at the Tsanawiyah State Madrasah 35 Jakarta.

The development of online art learning in the Tsanawiyah State Madrasah 35 Jakarta Environment is carried out with computerization and integration with each other. The teacher can provide material and assignments to be learned and answered by all students. From the answers to these assignments, the teacher will be given an assessment. The process of completing the material creation, assignment and assignment of these values will be present for the teachers. Students can study the material and answer assignments given by all their 
teachers. From the answers to these assignments, the teacher will be given an assessment. The process of completing the assignment answers will be present for students. Administrative staff will recapitulate the grades given by the teacher, recapitulate the presence of teachers and students.

\subsection{Data Flow Diagram}

The development of online art learning in the Tsanawiyah State Madrasah 35 Jakarta environment proposed in this study can be seen in the following data flow diagram.

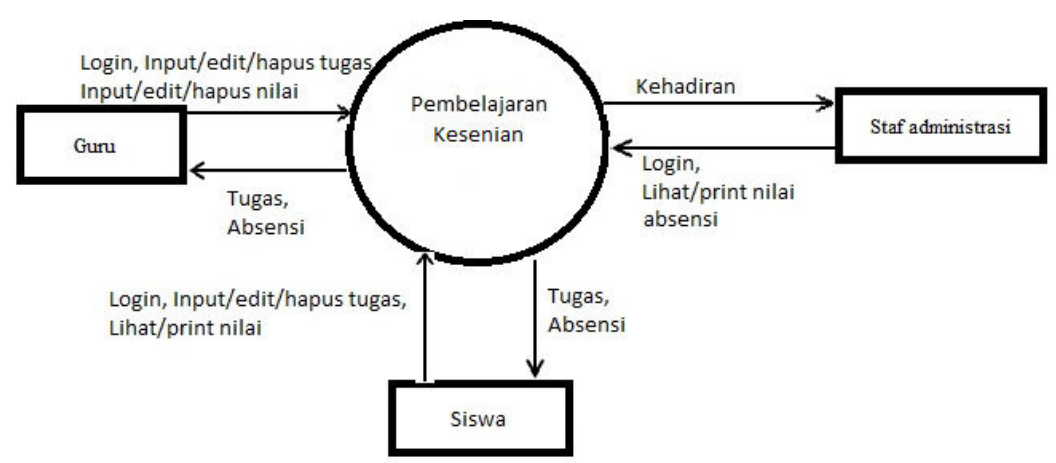

Fig. 2. Research Data Flow Diagram

The data flow diagram above illustrates the process of developing online art learning in the Tsanawiyah State Madrasah 35 Jakarta. The first academic community is the teacher, who can assign assignments and grades, make changes and can delete them in online art learning. The second academic community is students, who can answer assignments, see grades and print them. The third academic community is the administrative staff who can check or check grades, enter, edit, and delete grades if there are still those who haven't, forgotten or made mistakes in the assessment. In addition, administrative staff will provide information to students that grades can be seen and attendance has been made.

\subsection{Entity Relationship Diagram}

Furthermore, the proposed process of developing online learning in the Tsanawiyah State Madrasah 35 Jakarta environment can also be seen in the following diagram.

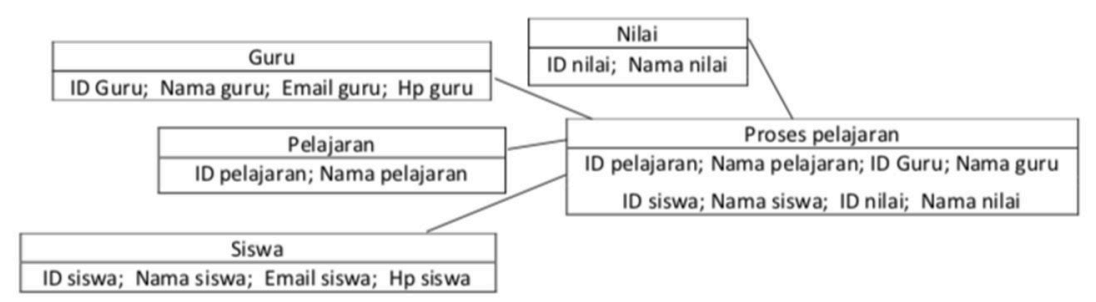

Fig. 3. Research Entity Relationship Diagram

In the entity relationship diagram, figure 3 above shows the relationship between existing entities. The teacher entity has the teacher id attribute, teacher name, teacher email, teacher 
cellphone. Student entities have student id attributes, student names, student e-mails, student cellphones. The value entity has the value id attribute, the value name. The lesson entity has the lesson id attribute, the name of the lesson. The learning process has the attribute lesson id, lesson name, teacher id, teacher name, student id, student name, class id, class name.

\subsection{User Interface and User Experience}

The development of the user interface and the user experience model in the development of online art learning in the Tsanawiyah State Madrasah 35 Jakarta environment, can be seen in the picture below.

\section{LOGIN}

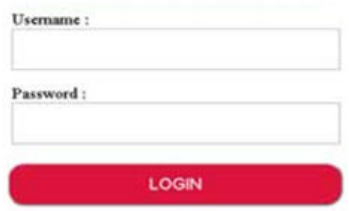

Fig. 4. Login Page

In figure 4 above, the pages included in the page model for developing the online art learning user interface or user interface are explained, so users can interact with the development model of online art learning in the Tsanawiyah State Madrasah 35 Jakarta environment.

\begin{tabular}{|c|c|}
\hline MTsN 35 Jakarta & Home \\
\hline KESENIAN & Guru \\
\hline
\end{tabular}

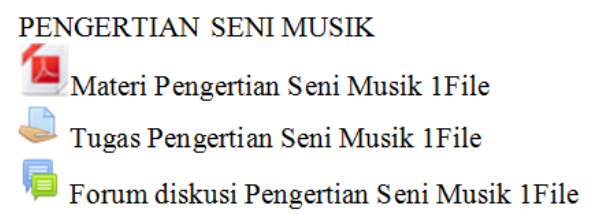

Fig. 5. Teacher and Subject Page Views

In figure 5 above explains the user interface or user page of the teacher page. On this teacher's page, the teacher must enter the correct username and password, so the teacher can interact with the academic information service management page model by providing students with materials, assignments and discussion forums. 


\begin{tabular}{|lc|}
\hline MTsN 35 Jakarta & Home \\
\hline $\begin{array}{l}\text { KESENIAN } \\
\text { Dashboard }\end{array}$ & Siswa \\
\hline
\end{tabular}

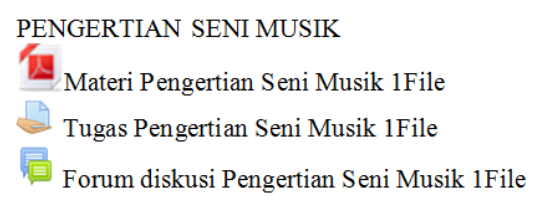

Fig. 6. Student Page Views and Assignments

In figure 6 above explains the user interface or user page of the student page. On this student page, students must enter the correct username and password, so students can interact with the academic information service management model. On this page students can read and study material, answer assignments and discussion forums that have been given by the teachers.

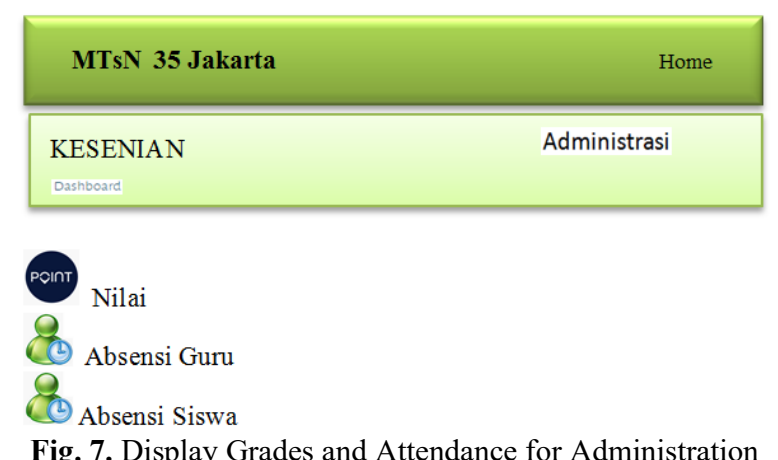

In figure 7 above explains the user interface of the menu page that will be used by all administrative staff, so that administrative staff can enter or register students in the online learning model, and so that administrative staff can also see and display students/teacher grades and attendance.

\subsection{Model Testing}

The results of the test scenario and the results of applying the online art learning model can be seen in the following table.

Table 2. Teacher Test Model

\begin{tabular}{cllcc}
\hline No & \multicolumn{1}{c}{ Testing Scenarios } & \multicolumn{1}{c}{ Expected Results } & Result & Conclusion \\
\hline 1 & Press the Login Icon & Successfully Displaying Menu & Accordingly & Valid \\
2 & $\begin{array}{l}\text { Press Item Input/ } \\
\text { Edit/Delete Material }\end{array}$ & Successfully Displaying Data Input & Accordingly & Valid \\
& $\begin{array}{l}\text { Press Item Input / Edit } \\
\text { / Selete Material }\end{array}$ & $\begin{array}{l}\text { Successfully Displayed Data Input } \\
\text { / Edit / Delete Task }\end{array}$ & Accordingly & Valid \\
& $\begin{array}{l}\text { Pressing Forum Input// } \\
\text { Successfully Displaying Input / }\end{array}$ & Accordingly & Valid \\
\hline
\end{tabular}


Table 3. Test Student Feature Models

\begin{tabular}{|c|c|c|c|c|}
\hline No & Testing Scenarios & Expected Results & Result & Conclusion \\
\hline 1 & Press the Login Icon & Successfully Displaying Menu & Accordingly & Valid \\
\hline 2 & $\begin{array}{l}\text { Pressing Item view / } \\
\text { read Material }\end{array}$ & $\begin{array}{l}\text { Successfully displaying } \\
\text { view / read Material }\end{array}$ & Accordingly & Valid \\
\hline 3 & $\begin{array}{l}\text { Press the Item Input / } \\
\text { Edit / Delete Task }\end{array}$ & $\begin{array}{l}\text { Successfully Displayed } \\
\text { Input / Edit / Delete Task }\end{array}$ & Accordingly & Valid \\
\hline 4 & $\begin{array}{l}\text { Pressing Forum Input / } \\
\text { Edit / Delete }\end{array}$ & $\begin{array}{l}\text { Successfully Displaying Input / } \\
\text { Edit / Delete Forums }\end{array}$ & Accordingly & Valid \\
\hline
\end{tabular}

Table 4. Test Staff Administration Model Feature

\begin{tabular}{|c|c|c|c|c|}
\hline No & Testing Scenarios & Expected Results & Result & Conclusion \\
\hline 1 & Press the Login Icon & Successfully Displaying Menu & Accordingly & Valid \\
\hline 2 & $\begin{array}{l}\text { Pressing Item Input / } \\
\text { Edit / Delete Grade }\end{array}$ & $\begin{array}{l}\text { Successfully Displaying Data } \\
\text { Input / Edit / Delete Grade }\end{array}$ & Accordingly & Valid \\
\hline 3 & $\begin{array}{l}\text { Manage } \quad \text { Teacher } \\
\text { attendance/ Edit/Delete }\end{array}$ & $\begin{array}{l}\text { Successfully Displaying Teacher } \\
\text { attendance Inputs / Edit / Delete }\end{array}$ & Accordingly & Valid \\
\hline 4 & $\begin{array}{l}\text { Manage Student } \\
\text { attendance/Edit/Delete }\end{array}$ & $\begin{array}{l}\text { Successfully Displaying Student } \\
\text { attendance Inputs / Edit / Delete }\end{array}$ & Accordingly & Valid \\
\hline
\end{tabular}

The table above is the result of testing an online learning model using black box testing. Of the three types of tests conducted, it was found that the application of online learning models of learning software that was developed functioned well.

\subsection{Interactive Model}

From the results of testing this online art learning model, the questionnaire was then distributed to the academic community involved in online art learning, namely one school principal, one deputy headmaster, twenty teachers, one hundred students and five administrative staff at the Tsanawiyah State Madrasah 35 Jakarta. The results of the questionnaire indicate that this online art learning model is easy, fast, accurate, and efficient because it is interactive and user friendly.

\section{Conclusions and Recommendations}

Based on the results of data analysis and data interpretation, the process of developing an online learning model in the Tsanawiyah State Madrasah 35 Jakarta provides facilities for school principals, deputy principals, teachers, students and administrative staff of the Tsanawiyah State Madrasah 35 Jakarta which are error free, more efficient, by utilizing information and communication technology services, so that it is expected to avoid the corona pandemic and maintain the quality of education that can be applied to the Tsanawiyah State Madrasah 35 Jakarta. In addition, the development of online art learning is able to provide the desired reporting data, in the form of art teaching and learning, values and the presence of teachers and students online.

Suggestions for further research are so that the development of online art learning can be applied to school units or other tertiary institutions so that it is expected to avoid the corona pandemic and maintain the quality of education. For development, it can be implemented using a mobile based application, so users can open applications through their gadgets. 


\section{Acknowledgments}

Thank you to Allah SWT for giving His guidance. Thank you to the Tsanawiyah State Madrasah 35 Jakarta and Trilogi University for providing support in this study.

\section{References}

[1] Al-Naibi, I., Al-Jabri, M., and Al-Kalbani, I., 2018. Promoting Students' Paragraph Writing Using EDMODO: An Action Research. TOJET vol. 17 issue 1, 2018, ISSN 2146-7242.

[2] Apsari, F.D.R., 2019. Management of Learning Music and Music Based on Information and Communication Technology (ICT) in SMP Negeri 1 Sambi Boyolali. Thesis of Muhammadiyah University Surakarta, 2019.

[3] CNN Indonesia, 2020. Reasons for Effective Social Distance Preventing Corona Transmission. https://www.cnnindonesia.com/ download March 23, 2020.

[4] Detik.com, 2020. About Social Distance, How the Government Prevents the Spread of Corona Virus. https://news.detik.com/ download March 23, 2020.

[5] Faisal P. and Zainul K., 2020. Information and communication technology utilization effectiveness in distance education systems. IJEBM, SAGE Journals | ISI, 12 (Jan-Dec 2020, 1-16 ISSN: 1847-9790, DOI: https://doi.org/10.1177/1847979020911872.

[6] Kusumastuti, E., 2014. Application of the Integrated Dance Learning Model for Elementary School Students. Journal Pulpit Elementary School. 1 (1): pp. 7-16, 2014.

[7] Mareza, L., 2017. Cultural Arts Education and Crafts (SBdP) As a General Intervention Strategy for Children with Special Needs. Scholaria 7 (1): 35 - 38, 2017.

[8] Medikantyo, 2020. Indonesia has the potential to be the center of the Corona Virus Pandemic due to Poor Health Services. https://news.okezone.com/ download March 23, 2020.

[9] Mukaromah, V.F., 2020. Trending \#DiRumahAjaTulu and Why Social Distancing Can Press Corona Virus Transmission? https://www.kompas.com/ download on March 23, 2020.

[10] Parvin, S., Panahi, S., and Velmurugan, C, 2019. Research Impact of the Iranian Publications on Social Networks in Scopus Indexed. Library of Philosophy and Practice (e-journal) 2397, https://digitalcommons.unl.edu/libphilprac/2397.

[11] Regulation of the Minister of Education and Culture of the Republic of Indonesia Number 57 Year 2014 concerning the 2013 Elementary School / Madrasah Ibtidaiyah Curriculum.

[12] Putsanra, D.V., 2020 A. List of Kemendikbud E-Learning, Online Schools to Prevent Corona. https://tirto.i $\overline{\mathrm{d}} /$ download on March 23, 2020.

[13] Putsanra, D.V., 2020_B. What Is Social Distancing and Self Quarantine to Prevent Corona. https://tirto.i $\overline{\mathrm{d} /}$ download on March 23, 2020.

[14] Rosala, D., 2016. Learning Culture and Art Based on Local Wisdom in Efforts to Build Student Character Education in Primary Schools. Rhythm 2 (1), 17-26, 2016, ISSN: $1412653 X$.

[15] Şahin, C., 2018. Social Media Addiction Scale - Student Form: The Reliability and Validity Study. TOJET vol. 17 issue 1, 2018, ISSN 2146-7242. 
[16] Sefmiwati, 2016. The Development of Craft Arts Learning Using Modeling Techniques Based on Scientific Approaches. JPGI 1 (1): 37-42, 2016, ISSN: 25413163.

[17] Setiawan, R., 2020. Corona Update in Indonesia: 1,285 Positive, 114 Dead, 64 Healed. https://tirto.id/ download on March 29, 2020.

[18] Suhaya, 2016. Art Education as a Support for Creativity. Journal of Education and Arts Studies, 1 (1): 1-15 April 2016, ISSN 2503-4626.

[19] Sutiyaso, 2017. Management of the Implementation of Cultural Arts Learning in SMA Negeri 1 Pulokulon Grobogan. University of Muhammadiyah Surakarta Thesis, 2017.

[20] Syakhruni, 2018. Development of Learning Materials for Art and Culture-Based Dance for High School Students in Makassar. UNM Anniversary National Seminar, 371-382, 2018, ISBN: 978-602-5554-35-3.

[21] Terziyan, V., 2017. Social Distance metric: from coordinates to neighborhoods. IJGIS vol. 31, nos. 11-12, 2401-2426 https://doi.org/10.1080/13658816.2017.1367796.

[22] Law Number 19 of 2005 concerning National Education Standards.

[23] Utami, N. 2018. Learning Art and Culture Using an Integrative Thematic Approach in Class II MIN 2 Bandar Lampung. Thesis of University of Lampung, 2018. 